\title{
mOrange2, a Genetically Encoded, pH Sensitive Fluorescent Protein, is an Alternative to BCECF-AM to Measure Intracellular pH to Determine NHE3 and DRA Activity
}

\author{
Rafiquel Sarker ${ }^{\mathrm{C}}$ Chung Ming Tse ${ }^{\mathrm{a}}$ Ruxian Lin ${ }^{\mathrm{a}} \quad$ George McNamara ${ }^{\mathrm{a}}$ \\ Varsha Singh $^{a}$ Mark Donowitz ${ }^{\mathrm{a}, \mathrm{b}}$ \\ aDivision of Gastroenterology, Department of Medicine, The Johns Hopkins University School of \\ Medicine, Baltimore, MD, USA, 'Department of Physiology, The Johns Hopkins University School of \\ Medicine, Baltimore, MD, USA
}

\section{Key Words}

Intracellular pH • mORANGE2 - NHE3 - DRA

\begin{abstract}
Background/Aims: NHE3 $\left(\mathrm{Na}^{+} / \mathrm{H}^{+}\right.$exchanger3) and SLC26A3 $\left(\mathrm{Cl}^{-} / \mathrm{HCO}_{3}^{-}\right.$exchanger, DRA) are the major components of the intestinal neutral $\mathrm{NaCl}$ absorptive process and based on the intestinal segment, contribute to $\mathrm{HCO}_{3}{ }^{-}$absorption and $\mathrm{HCO}_{3}{ }^{-}$secretion. $\mathrm{NHE3}$ and DRA are highly regulated by changes in second messengers, CAMP, CGMP and $\mathrm{Ca}^{2+}$. Precise and convenient measurement of exchanger activity is necessary to allow rapid study of physiologic and pharmacologic functions. Some epithelial cells are difficult to load with AM ester dyes and loading may not be uniform. Methods: The use of a genetically modified fluorescent protein, mOrange 2 was explored as an intracellular $\mathrm{pH}$ sensor protein to measure exchange activity of NHE3 and DRA. The model used was FRT cells stably expressing NHE3 or DRA with intracellular $\mathrm{pH}$ measured by changes of mOrange 2 fluorescence intensity. Intracellular $\mathrm{pH}$ was monitored using a) Isolated single clones of FRT/mOrange2/HA-NHE3 cells studied in a confocal microscope with time-lapse live cell imaging under basal conditions and when NHE3 was inhibited by exposure to forskolin and stimulated by dexamethasone, b) coverslip grown FRT/mOrange2 cells expressing NHE3 or DRA using a computerized fluorometer with a perfused cuvette with standardization of the mOrange 2 absorption and emission signal using $\mathrm{K}^{+} /$Nigericin as an internal standard in each experiment. Results: A similar rate of intracellular alkalization by $\mathrm{Na}^{+}$addition in cells expressing $\mathrm{NHE} 3$ and by $\mathrm{Cl}^{-}$removal in cells expressing DRA was found in mOrange 2 expressing cells compared to the same cells loaded with BCECF-AM,
\end{abstract}




\section{Cellular Physiology Cell Physiol Biochem 2022;56:39-49 \\ \begin{tabular}{l|l} 
Co 2022 The Author(s). Published by \\
\hline
\end{tabular} \\ \begin{tabular}{l|l} 
Published online: 26 January 2022 Cell Physiol Biochem Press GmbH\&Co. KG \\
\hline
\end{tabular} \\ Sarker et al.: mOrange2 to Measure NHE3 and DRA Activity}

both using the same $\mathrm{pH}$ calibration with $\mathrm{K}^{+} /$Nigericin. Using mOrange2 as the $\mathrm{pH}$ sensor, NHE3 basal activity was quantitated and shown to be inhibited by forskolin and stimulated by dexamethasone, and DRA was oppositely shown to be stimulated by forskolin, responses similar to results found using BCECF-AM. Conclusion: This study demonstrates that mOrange 2 protein can be an effective alternate to BCECF-AM in measuring intracellular $\mathrm{pH}$ (preferred setting Ex520nm, Em 563nm) as affected by NHE3 and DRA activity, with the advantage, compared to AM ester dyes, that genetic expression can provide uniform expression of the $\mathrm{pH}$ sensor.

\section{Introduction}

(C) 2022 The Author(s). Published by Cell Physiol Biochem Press GmbH\&Co. KG

Diarrhea related diseases remain a major cause of morbidity and mortality worldwide. Reduction of intestinal $\mathrm{Na}^{+}$absorption occurs in almost all diarrheal diseases. The epithelial $\mathrm{Na}^{+} / \mathrm{H}^{+}$exchanger SLC9A3 (NHE3) is linked to the $\mathrm{Cl}^{-} / \mathrm{HCO}_{3}{ }^{-}$exchanger SLC26A3 (DRA) to produce the electroneutral $\mathrm{NaCl}$ absorptive process in the mammalian small intestine and colon. Both NHE3 and DRA are acutely regulated as part of the neutral $\mathrm{NaCl}$ absorptive process, although this regulation appears to be coordinated but with different characteristics. In all cells in which it has been studied, NHE3 regulation mimics the regulation of neutral $\mathrm{NaCl}$ absorption, being active under basal conditions and being both inhibited and stimulated in cell models by various mimics of digestive physiology. NHE3 is divided into two distinct domains: $\mathrm{N}$-terminus transmembrane domain which perform $\mathrm{Na}^{+} / \mathrm{H}^{+}$exchange, while the $\mathrm{C}$-terminal cytosolic domain is regulatory and plays an important role in trafficking.

NHE3 and more recently DRA activities are usually measured indirectly by measuring the rate of alkalization of the intracellular space using the $\mathrm{pH}$ sensitive dye, BCECF-AM, with consideration of intracellular buffering capacity. Recent advances in fluorescent proteins have paved the way to use them to measure intracellular $\mathrm{pH}$. While loading via coupling to acetoxy methyl esters in most cells has produced adequate loading of BCECF, this has been difficult in some cells, particularly epithelial cells, and loading may not be uniform. This led us to seek an alternate $\mathrm{pH}$ sensor for physiologic studies, which could be expressed uniformly, ideally a genetically encoded sensor. mOrange 2 is a $26.8 \mathrm{kDa}$ monomer protein derived from mOrange mutations at four different sites (Q64H/F99Y/E160K/G196D) that significantly increased its photo-stability $\left(\mathrm{t}_{1 / 2}\right.$ is $\left.228 \mathrm{sec}\right)$. mOrange 2 has a pKa value of 6.5 which is suitable for measuring pHs between pH 6.0 and above 7.0, which is the $\mathrm{pH}$ range over which both NHE3 and DRA are active.

Second messengers normally inhibit activity of NHE3, while growth factors and some hormones are stimulatory. DRA is also regulated by second messengers and altered as part of diarrheal diseases in the intestine. Specific inhibitors of both NHE3 and DRA are available $[1,2]$ and a small molecule stimulator of NHE3 has also been developed that has the potential for treatment of diarrheal disease [3].

FRT (Fisher rat thyroid) cells have been used as an epithelial cell model to study CFTR and develop drugs to inhibit DRA and both stimulate and inhibit CFTR [4,5]. We demonstrate that mOrange 2 is an effective and sensitive $\mathrm{pH}$ sensor probe that can be genetically expressed and used to quantitate NHE3 and DRA activity in epithelial cells.

\section{Materials and Methods}

\section{Cells and plasmids}

FRT (Fischer rat thyroid) epithelial cells were grown and maintained in DMEM-F12 medium supplemented with L-Glutamine, $15 \mathrm{mM}$ HEPES, $10 \%$ fetal bovine serum and $50 \mathrm{U} / \mathrm{ml}$ penicillin/ streptomycin at $37^{\circ} \mathrm{C}$ in $5 \% \mathrm{CO}_{2}$ atmosphere. The mOrange 2 construct was made by cloning synthetic mOrange2 seq, (mammalian codon optimized, sequence ID: DQ336159.1) into pcDNA3.1/Zeo (+) 


\title{
Cellular Physiology Cell Physiol Biochem 2022;56:39-49 \begin{tabular}{l|l|l}
\hline DOl: 10.33594/000000493 & (c) 22 The Author(s). Published by
\end{tabular} and Biochemistry Published online: 26 January 2022 Cell Physiol Biochem Press GmbH\&Co. KG

\begin{abstract}
atggtgagca agggcgagga gaataacatg gccatcatca aggagttcat gcgcttcaag gtgcgcatgg agggctccgt gaacggccac gagttcgaga tcgagggcga gggcgagggc cgccctacg agggctttca gaccgctaag ctgaaggtga ccaagggtgg cccctgccc ttcgcctggg acatcctgtc ccctcatttc acctacggct ccaaggccta cgtgaagcac cccgccgaca tcccegacta cttcaagctg tccttccccg agggcttcaa gtgggagcgc gtgatgaact acgaggacgg cggcgtggtg accgtgaccc aggactcctc cctgcaggac ggcgagttca tctacaaggt gaagctgcgc ggcaccaact tccctccga cggcccegtg atgcagaaga agaccatggg ctgggaggcc tcctccgagc ggatgtaccc cgaggacggt gcctgaagg gcaagatcaa gatgaggctg aagctgaagg acggcggcca ctacacctcc gaggtcaaga ccacctacaa ggccaagaag cccgtgcagc tgcccggcgc ctacatcgtc gacatcaagt tggacatcac ctcccacaac gaggactaca ccatcgtgga acagtacgaa cgcgccgagg gccgccactc caccggcggc atggacgagc tgtacaagtg a
\end{abstract}

vector (Epoch Life Science, Inc, Sugar Land, TX 77496). FRT cells were transfected with pCDNA 3.1/ mOrange2(Zeo)+ vector and selected with zeocin $(10 \mu \mathrm{g} / \mathrm{ml})$. Single clones of FRT/mOrange2 cells were isolated microscopically (Keyence microscope) based on the brightest mOrange 2 expression. Selected clone of FRT/mOrange2 cells were transfected with pCDNA3.1/HA-NHE3 plasmid with G418 as the selection marker. Using two selection markers (Zeocin and G418), high HA-NHE3 expressing single clones were selected based on immunoblot analysis.

\section{Microscopic imaging of mOrange2 to measure NHE3 activity}

FRT cells transiently or stably expressing mOrange2 and HA-NHE3 were seeded into glass bottom dishes (FluoroDishes, WPI, Inc) $\left(1 \times 10^{5}\right.$ cells/well) and grown for 4-5 days. To examine the pH sensing ability of mOrange2, cells were incubated with $20 \mathrm{mM} \mathrm{NH}_{4} \mathrm{Cl}\left(108 \mathrm{mM} \mathrm{NaCl}, 5 \mathrm{mM} \mathrm{KCl}, 2 \mathrm{mM} \mathrm{CaCl}, 1 \mathrm{mM} \mathrm{MgSO}_{4^{\prime}}\right.$ $1 \mathrm{mM} \mathrm{NaH}{ }_{2} \mathrm{PO}_{4}, 25 \mathrm{mM}$ glucose, $20 \mathrm{mM}$ HEPES, and $40 \mathrm{NH}_{4} \mathrm{Cl}, \mathrm{pH} 7.4$ ) at $37^{\circ} \mathrm{C}$ for $15-20$ min and washed three times with $\mathrm{TMA}^{+}$solution $\left(130 \mathrm{mM}\right.$ tetramethylammonium chloride, $5 \mathrm{mM} \mathrm{KCl}, 2 \mathrm{mM} \mathrm{CaCl}_{2}, 1 \mathrm{mM}$ $\mathrm{MgSO}_{4}, 1 \mathrm{mM} \mathrm{NaH}_{2} \mathrm{PO}_{4}, 25 \mathrm{mM}$ glucose, and $20 \mathrm{mM}$ HEPES, $\mathrm{pH}$ 7.4). Adding $\mathrm{NH}_{4} \mathrm{Cl}$ causes intracellular alkalization and its removal causes rapid intracellular acidification which was used for initiating $\mathrm{pH}$ recovery studies [6]. The cells in glass bottom dishes covered with $100 \mu \mathrm{l}$ TMA solution were studied on the microscope. Live images of mOrange2 fluorescence were obtained at $\mathrm{Ex}_{514 \mathrm{~nm}}$ and $\mathrm{Em}_{545-614 \mathrm{~nm}}$ every second with an Olympus FV30000RS confocal microscope (20x/0.75na objective) using the resonance mode at $37^{\circ} \mathrm{C}$ with cells in an OkoLab stage top plus transparent shroud incubator. After baseline fluorescence was established, $900 \mu \mathrm{l} \mathrm{Na}^{+}$solution $\left(138 \mathrm{mM} \mathrm{NaCl}, 5 \mathrm{mM} \mathrm{KCl}, 2 \mathrm{mM} \mathrm{CaCl}, 1 \mathrm{mM} \mathrm{MgSO} 4_{4}, 1 \mathrm{mM} \mathrm{NaH}_{2} \mathrm{PO}_{4}, 25 \mathrm{mM}\right.$ glucose, and $20 \mathrm{mM}$ HEPES, pH 7.4) was added. A time series was acquired with $512 \times 512$ pixels, 16 line average, $300 \times 300-\mu \mathrm{m}$ field of view for 300 time points at $\sim 1 \mathrm{~s}$ per time point. Addition of $\mathrm{Na}^{+}$activates NHE3 activity and the intensity of mOrange2 fluorescence increased with intracellular alkalinization.

\section{NHE3 activity measured in a computerized fluorometer}

$\mathrm{Na}^{+} / \mathrm{H}^{+}$exchange activity was determined in the FRT, FRT/HA-NHE3, or FRT/mOrange2/HA-NHE3 cells grown on glass cover slides for 3-5 days. Cells without mOrange2 were loaded with BECEF-AM $(10 \mu \mathrm{M})$, as described [7]. Cells were incubated in $20 \mathrm{mM} \mathrm{NH}_{4} \mathrm{Cl}$ for $15-20 \mathrm{~min}$ at $37^{\circ} \mathrm{C}$. The slides were mounted in a cuvette that allowed apical and basolateral perfusion, placed in a fluorometer (Horiba-Photon Technology, Lawrenceville, $\mathrm{NJ}$ ), and perfused with $\mathrm{TMA}^{+}$solution to rapidly remove $\mathrm{Na}^{+}$in addition to $\mathrm{NH}_{4}^{+}$for intracellular acidification. After 2-3 min, the apical $\mathrm{TMA}^{+}$medium was replaced with $\mathrm{Na}^{+}$medium perfused at $1 \mathrm{ml} / \mathrm{min}$. In studies of regulation of transport, cells were pretreated with forskolin $(10 \mu \mathrm{M}$, 20 min pretreatment) or dexamethasone $(1 \mu \mathrm{M}, 5$ hours pretreatment). HOE-694 $(10 \mu \mathrm{M})$ was used in the $\mathrm{TMA}^{+}$and $\mathrm{Na}^{+}$solutions to inhibit endogenous NHE1 activity. In cell loaded with BCECF-AM, changes in $\mathrm{pH}_{\mathrm{i}}$ were monitored by recording emission alternating between 440 and $490 \mathrm{~nm}$ with excitation at $530 \mathrm{~nm}$. In cells with mOrange $2, \mathrm{pH}_{\mathrm{i}}$ was monitored by recording the emission signal at $\mathrm{Em}_{564 \pm 3 \mathrm{~nm}}$ after excitation at ${ }_{545 \pm 3 \mathrm{~nm}}$. The emission fluorescence was calibrated to $\mathrm{pH}_{\mathrm{i}}$ with the high $\mathrm{K}^{+} /$nigericin method on each coverslip, as described previously [8, 9]. Initial rates of $\mathrm{Na}^{+}$-dependent intracellular alkalinization were calculated for a given $\mathrm{pH}_{\mathrm{i}}$ over the first 1 min (within the linear phase) of $\mathrm{Na}^{+}$exposure and expressed as $\Delta \mathrm{pH} / \Delta t$. Calculation used Origin 8.0 software (OriginLab, Northampton, MA). Means \pm SE were determined from at least three experiments. Since excitation and emission spectra of mOrange 2 have significant overlap, the best excitation wave lengths were empirically determined at which emission most directly correlated with intracellular pHs between 6.0 to 8.0 . 


\section{Cellular Physiology Cell Physiol Biochem 2022;56:39-49 \\ \begin{tabular}{l|l}
\hline DOl: 10.33594/000000493 & 2022 The Author(s). Published by
\end{tabular} \\ Published online: 26 January 2022 Cell Physiol Biochem Press GmbH\&Co. KG \\ Sarker et al.: mOrange2 to Measure NHE3 and DRA Activity}

Measuring $\mathrm{Cl} / \mathrm{HCO}_{3}^{-}$exchange activity

$\mathrm{Cl}^{-} / \mathrm{HCO}_{3}-$ exchange activity was measured fluorometrically using mOrange 2 or, as previously described, with BCECF-AM [10]. Measurements were in mOrange2 expressing cells or cells without mOrange2 but loaded with BCECF-AM $(10 \mu \mathrm{M})$ in $\mathrm{Na}^{+}$solution $\left(138 \mathrm{mmol} / \mathrm{L} \mathrm{NaCl}, 5 \mathrm{mmol} / \mathrm{L} \mathrm{KCl}, 2 \mathrm{mmol} / \mathrm{L} \mathrm{CaCl}_{2}\right.$, $1 \mathrm{mmol} / \mathrm{L} \mathrm{MgSO}_{4}, 1 \mathrm{mmol} / \mathrm{L} \mathrm{NaH}_{2} \mathrm{PO}_{4}, 10 \mathrm{mmol} / \mathrm{L}$ glucose, $20 \mathrm{mmol} / \mathrm{L}$ HEPES, $\mathrm{pH}$ 7.4) for 20-30 minutes at $37^{\circ} \mathrm{C}$ and mounted in a fluorometer. Cells were perfused with $\mathrm{Cl}^{-}$solution $(110 \mathrm{mmol} / \mathrm{L} \mathrm{NaCl}, 5 \mathrm{mmol} / \mathrm{L} \mathrm{KCl}$, $1 \mathrm{mmol} / \mathrm{L} \mathrm{CaCl}_{2}, 1 \mathrm{mmol} / \mathrm{L} \mathrm{MgSO}_{4}, 10 \mathrm{mmol} / \mathrm{L}$ glucose, $25 \mathrm{mmol} / \mathrm{L} \mathrm{NaHCO}_{3}, 1 \mathrm{mmol} / \mathrm{L}$ amiloride, $5 \mathrm{mmol} / \mathrm{L}$ HEPES, 95\% $\mathrm{O}_{2} / 5 \% \mathrm{CO}_{2}$ ) or $\mathrm{Cl}^{-}$-free solution ( $110 \mathrm{mmol} / \mathrm{L}$ Na-gluconate, $5 \mathrm{mmol} / \mathrm{L} \mathrm{K}$-gluconate, $5 \mathrm{mmol} / \mathrm{L}$ Ca-gluconate, $1 \mathrm{mmol} / \mathrm{L} \mathrm{Mg-gluconate,} 10 \mathrm{mmol} / \mathrm{L}$ glucose, $25 \mathrm{mmol} / \mathrm{L} \mathrm{NaHCO}_{3}, 1 \mathrm{mmol} / \mathrm{L}$ amiloride, $5 \mathrm{mmol} / \mathrm{L}$ HEPES, $95 \% \mathrm{O}_{2} / 5 \% \mathrm{CO}_{2}$ ) with a flow rate of $1 \mathrm{~mL} / \mathrm{min}$. The switch between $\mathrm{Cl}^{-}$solution and $\mathrm{Cl}^{-}$-free solution causes $\mathrm{HCO}_{3}{ }^{-}$uptake across the cell membrane performed by $\mathrm{Cl}^{-} / \mathrm{HCO}_{3}{ }^{-}$exchanger(s), and the resulting change in $\mathrm{pH}_{\mathrm{i}}$ was recorded. Multiple rounds of removing/replenishing extracellular $\mathrm{Cl}^{-}$were performed to measure the $\mathrm{Cl}^{-} / \mathrm{HCO}_{3}{ }^{-}$exchange activity under basal conditions as a time control as well as in the presence of forskolin $(10 \mu \mathrm{M})$. The cells were exposed to forskolin for at 4-5 minutes before their effects on $\mathrm{Cl}^{-} / \mathrm{HCO}_{3}^{-}$exchange activity was determined. At the end of each experiment, $\mathrm{pH}_{\mathrm{i}}$ was calibrated using the same $\mathrm{K}^{+}$/nigericin clamp solutions as used for the $\mathrm{Na}^{+} / \mathrm{H}^{+}$exchange determinations. The rate of initial alkalinization after the switch from $\mathrm{Cl}^{-}$solution to $\mathrm{Cl}^{-}$-free solution over the first 1 min (within the linear phase) was calculated using Origin 8.0 software (OriginLab, Northampton, MA).

\section{Immunoblot analysis}

FRT/mOrange2/HA-NHE3 stable cells or FLAG-DRA transfected cells were rinsed 3 times with phosphate-buffered saline and harvested in phosphate-buffered saline by scraping. Cell pellets were collected in 1.5-ml Eppendorf tubes by centrifugation at $5000 \mathrm{rpm}$ for 5 minutes. Cells were mixed with HEPES lysis buffer containing protease inhibitors (20 mM HEPES, pH 7.4, $150 \mathrm{mM} \mathrm{NaCl}, 50 \mathrm{mM} \mathrm{NaF}$, $1 \mathrm{mM} \mathrm{Na}_{3} \mathrm{VO}_{4}$ and $1 \%$ Triton X-100) and homogenized by passing them through a 1-ml syringe/26-gauge needle (20X) and rotated for $\sim 30$ minutes at $4^{\circ} \mathrm{C}$ to maximize solubilization. After removal of insoluble cell debris by centrifugation $(10,000 \mathrm{rpm} \times 10 \mathrm{~min})$, the protein concentrations were measured with the BioRad protein assay, Bradford dye-binding method. Total lysate protein $30 \mu \mathrm{g}$, was incubated with Laemmli sample buffer at $37^{\circ} \mathrm{C}$ for 15 minutes, separated by $10 \%$ SDS-PAGE, and transferred onto a nitrocellulose membrane. The blot was blocked with $5 \%$ nonfat milk, probed with primary antibodies against HA (mouse monoclonal, Biolegend, Cat\# MMS-101P, 1:1000 dilution) or FLAG (mouse monoclonal, Sigma-Aldrich, Cat\# F1804, 1:2000 dilution), glyceraldehyde-3-phosphate dehydrogenase (mouse monoclonal, Sigma-Aldrich, Cat\# G8795, 1:5000 dilution) overnight at $4^{\circ} \mathrm{C}$, followed by IR-dye secondary antibody against mouse IgG $(1: 10,000)$ for 1 hour at room temperature. Protein bands were visualized using an Odyssey CLx system and quantitated with Image Studio software (LI-COR Biosciences, Lincoln, NE).

\section{Results}

Endogenous and exogenous $\mathrm{Na}^{+} / \mathrm{H}^{+}$exchange activity in FRT cells

FRT cells were chosen to establish a cell model for the NHE3 activity assay using mOrange 2 as a $\mathrm{pH}$ sensor probe, based on their previous use for transport assays and drug development $[4,5]$. Endogenous $\mathrm{Na}^{+} / \mathrm{H}^{+}$exchange activity was quantitated in wild type FRT cells using BCECF-AM dye. FRT cells had a large amount of $\mathrm{Na}^{+} / \mathrm{H}^{+}$exchange activity $(0.45$ $\Delta \mathrm{pH} / \mathrm{min}$ ) which was nearly entirely abolished in the presence of $10 \mu \mathrm{M}$ HOE-694 (Fig. 1A), consistent with this representing NHE1. FRT cells with HA-NHE3 expression had a higher $\mathrm{Na}^{+} / \mathrm{H}^{+}$exchange activity $(0.69 \pm 0.08 \Delta \mathrm{pH} / \mathrm{min})$. In the presence of $10 \mu \mathrm{M} \mathrm{HOE}-694, \mathrm{Na}^{+} / \mathrm{H}^{+}$ exchange activity was reduced to $\sim$ half $(0.34 \pm 0.03 \Delta \mathrm{pH} / \mathrm{min})$ (Fig. $1 \mathrm{~B}, \mathrm{C})$. These experiments indicate that FRT cells have endogenous $\mathrm{Na}^{+} / \mathrm{H}^{+}$exchange activity, most probably due to the presence of NHE1, which was inhibited by $10 \mu \mathrm{M}$ HOE-694. Exogenous expression of HA-NHE3 represents the difference between total $\mathrm{Na}^{+} / \mathrm{H}^{+}$exchange and that after $\mathrm{HOE}-694$ exposure and the results indicate this was a modestly overexpressing model. 


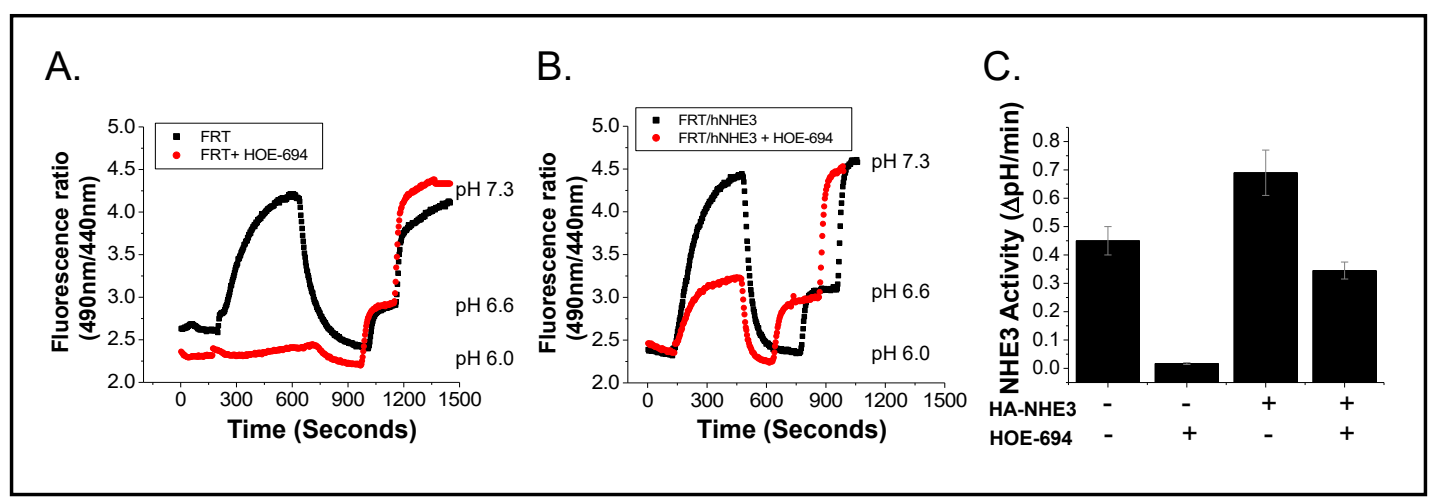

Fig. 1. Endogenous and exogenous $\mathrm{Na}^{+} / \mathrm{H}^{+}$activity in FRT cells. $\mathrm{Na}^{+} / \mathrm{H}^{+}$exchange activity measured in FRT cells (A) and in FRT/HA-NHE3 cells (B) in the absence (squares) and presence of $10 \mathrm{uM} \mathrm{HOE}-694$ (circles) using a computerized fluorometer with BCECF-AM as the pH indicator dye. NHE3 activity was measured from the initial rates of $\mathrm{Na}^{+}$-dependent intracellular alkalinization. Calculated NHE3 activities are shown in bar graph (C).

Fig. 2. Testing mOrange 2 as $\mathrm{pH}$ sensor protein in FRT cells. FRT/HA-NHE3 cells grown on the glass bottom dishes were transfected with the pCDNA/ mOrange 2 plasmid. $\mathrm{NH}_{4} \mathrm{Cl}$ and TMA treated cells were monitored in an Olympus FV3000RS confocal microscope to observe $\mathrm{Na}^{+} / \mathrm{H}^{+}$exchanger driven intracellular alkalization as detected by morange 2 as pH sensor. A time series was acquired with $512 \times$ 512 pixels, $300 \times 300-\mu$ m field of view for 300 time points at $\sim 1 \mathrm{~s}$ per time point. Addition of $\mathrm{Na}^{+}$solution stimulated NHE3 activity and intensity of mOrange2 fluorescence increased with intracellular alkalinization. Still images of mOrange2 intensity at indicated time points are shown (A). Intensity of mOrange2 fluorescence was quantitated by MetaMorph and plotted (B).

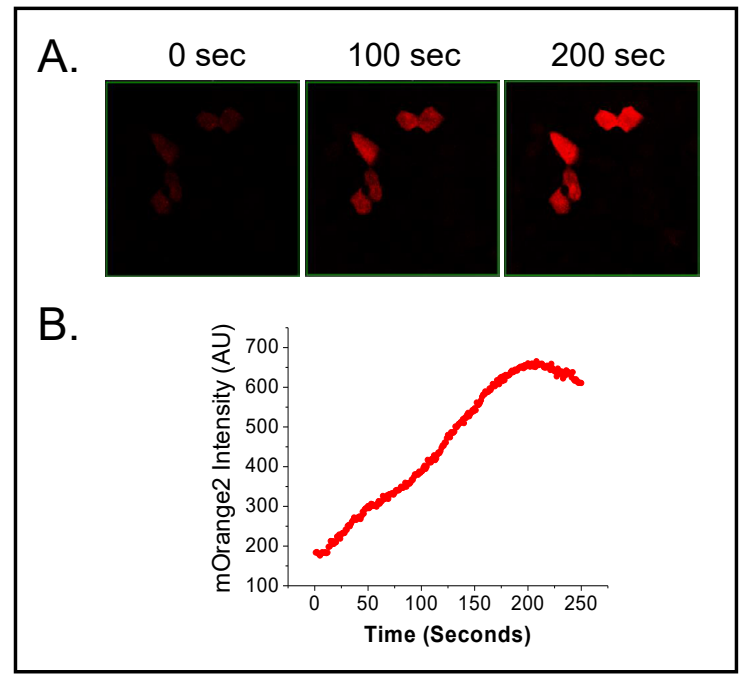

\section{Expression and testing mOrange2 as $\mathrm{pH}$ sensor protein}

The $\mathrm{pH}$ sensing ability of mOrange 2 as a genetically modified $\mathrm{pH}$ sensor protein was evaluated in the FRT/HA-NHE3 cells. FRT/HA-NHE3 cells grown in the glass bottom dish were transiently transfected with pCDNA/mOrange2 plasmid. After serum starvation and $\mathrm{NH}_{4} \mathrm{Cl} / \mathrm{TMA}$ acidification, live cell imaging was begun with $\mathrm{Na}+$ media addition. A rapid $\mathrm{Na}^{+}$ dependent change in fluorescent intensity of mOrange 2 was observed due to intracellular alkanization by $\mathrm{Na}^{+} / \mathrm{H}^{+}$exchange activity (Fig. $2 \mathrm{~A}$ ). A time series acquired with $512 \times 512$ pixels for 300 time points at $\sim 1$ s per time point in Olympus FV30000RS confocal microscope was quantitated by MetaMorph. Maximum mOrange2 intensity was observed within 3-4 min of $\mathrm{Na}^{+}$addition (Fig. 2B). This observation confirms that mOrange2 senses intracellular $\mathrm{pH}$ change in FRT/HA-NHE3/m-Orange2 cells.

\section{Stable cell lines of FRT/HA-NHE3/mOrange2}

Several single clones of FRT/HA-NHE3/mOrange2 were manually selected that had the highest percent ( $>95 \%$ ) of mOrange 2 positive cells and high, uniform expression of HA-NHE3. Expression of HA-tagged NHE3 was examined in FRT/mOrange 2 cells by western blot which is shown in Fig. 3A. Two clones \#6 and \#17 were examined microscopically to evaluate the change of mOrange2 intensity with intracellular alkalinization by NHE3. NHE1 expression 


\section{Cellular Physiology Cell Physiol Biochem 2022;56:39-49 \\ \begin{tabular}{ll|l} 
and Biochemistry $10.33594 / 000000493$ & $\begin{array}{l}\text { Published online: } 26 \text { January } 2022 \\
\text { Pell Physiol Biochem Press GmbH\&Co. KG }\end{array}$ \\
\hline
\end{tabular} \\ Sarker et al.: mOrange2 to Measure NHE3 and DRA Activity}

in cells not expressing NHE3 is shown in the upper panel of Fig. 3B, while clones with high NHE3 expression and with NHE1 inhibited by $10 \mu \mathrm{M}$ amiloride are shown in the other two panels. NHE3 clones \#6 and \#17 were studied further in the presence of $10 \mu \mathrm{M}$ amiloride (Fig. 3C). Maximum alkalization with $\mathrm{Na}^{+}$exposure, was observed within 2 to 3 minutes. We then tested the effect of forskolin on NHE3 activity indicated by a change in mOrange2 intensity microscopically. Forskolin treatment reduced the intensity of mOrange2 ( 45\%) compared to untreated cells (Fig. 3C shows triplicate traces of cells from a single experiment). This result indicates that using mOrange 2 as $\mathrm{pH}$ sensor protein can reproducibly detect $\mathrm{Na}^{+} / \mathrm{H}^{+}$ exchange activity in live cells under basal and inhibited conditions microscopically.

\section{Emission scan for mOrange2 fluorescence sensitivity to intracellular pH of FRT/HA-NHE3/} mOrange2 cells with PTI system

Excitation and emission spectra of mOrange2 have significant overlap. Therefore, we determined the excitation wavelength at which there was lowest overlap on emission spectra of mOrange 2 fluorescence while still providing a detectable signal at different intracellular pHs. Excitation at $520 \pm 3 \mathrm{~nm}$ had very little overlap with mOrange 2 emission. The sensitivity of mOrange2 to different intracellular pHs was determined. FRT/HA-NHE3/ mOrange 2 cells grown on glass cover slip were perfused with K-clamp solution at indicated $\mathrm{pHs}$ and emission spectra were collected between 545-580 nm (maximum $564 \mathrm{~nm}$ ) at $520 \mathrm{~nm}$ excitation. As shown in Fig. 4A, mOrange 2 is very sensitive at intracellular $\mathrm{pH}$ range between 6.0 to 8.0. mOrange2 is insensitive at $\mathrm{pH} 5.5$ and less sensitive at $\mathrm{pH}$ above 8.0. A pH curve of mOrange2 fluorescence (emission $563 \mathrm{~nm}$ ) in FRT/HA-NHE3/mOrange2 cells is shown in Fig.4B. mOrange2 fluorescence intensity is linear between $\mathrm{pH} 6.0$ and $\mathrm{pH}$ 8.0, with the estimated $\mathrm{Kd}$ of $\sim 6.7 \mathrm{pH}$.

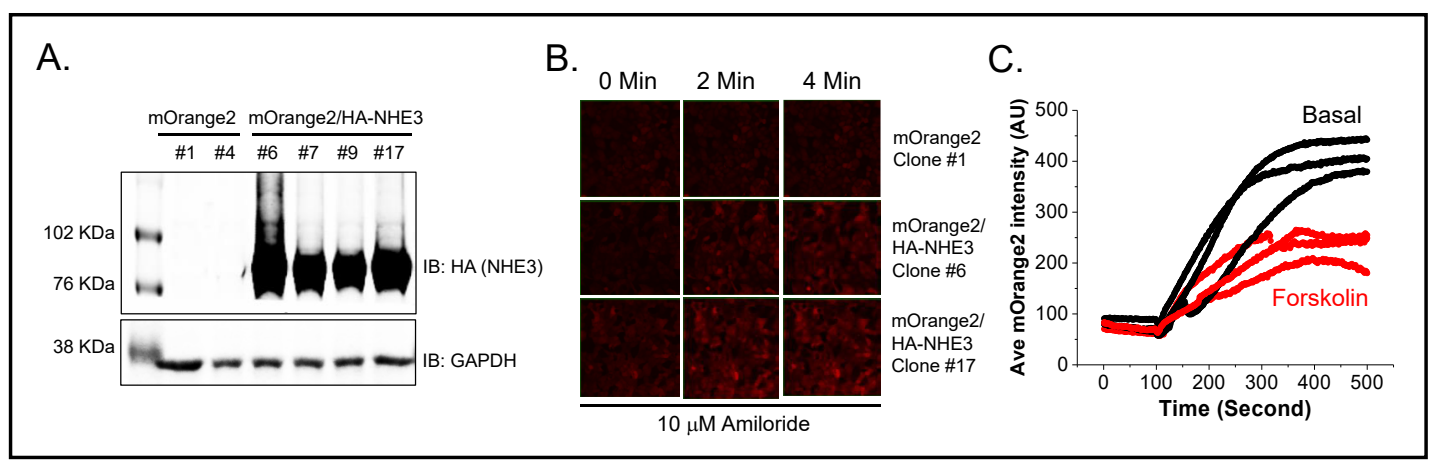

Fig. 3. Single clones of FRT cells stably expressing HA-NHE3 and mOrange 2 were isolated and studied after expansion. After several rounds of screening, a few single clones of FRT/mOrange2/HA-NHE3 were selected for study of NHE3 activity. HA-NHE3 expression in FRT/mOrange2 cells was verified by western blot analysis using HA monoclonal antibody and GAPDH as a loading control (A). Microscopically, NHE3 driven intracellular alkalinization was visible with mOrange2 in Clone \#6, \#17 in the presence of $10 \mu \mathrm{M}$ amiloride but was not visible in Clone \#1 which does not express NHE3 and was then used as a negative control. Confocal still images taken at different time points are shown in (B). In a mixed clone of FRT/mOrange2/HA-NHE3 cells, the effect of $10 \mu \mathrm{M}$ forskolin on NHE3 driven intracellular alkalization was examined microscopically. Forskolin treatment of cells for 15 minutes significantly decreased mOrange 2 fluorescence intensity compared with untreated cells. Microscopic data of mOrange2 fluorescence intensity over time of three sets of cells for basal and Forskolin treatment from a single experiment were calculated using Metamorph and are plotted (C). 


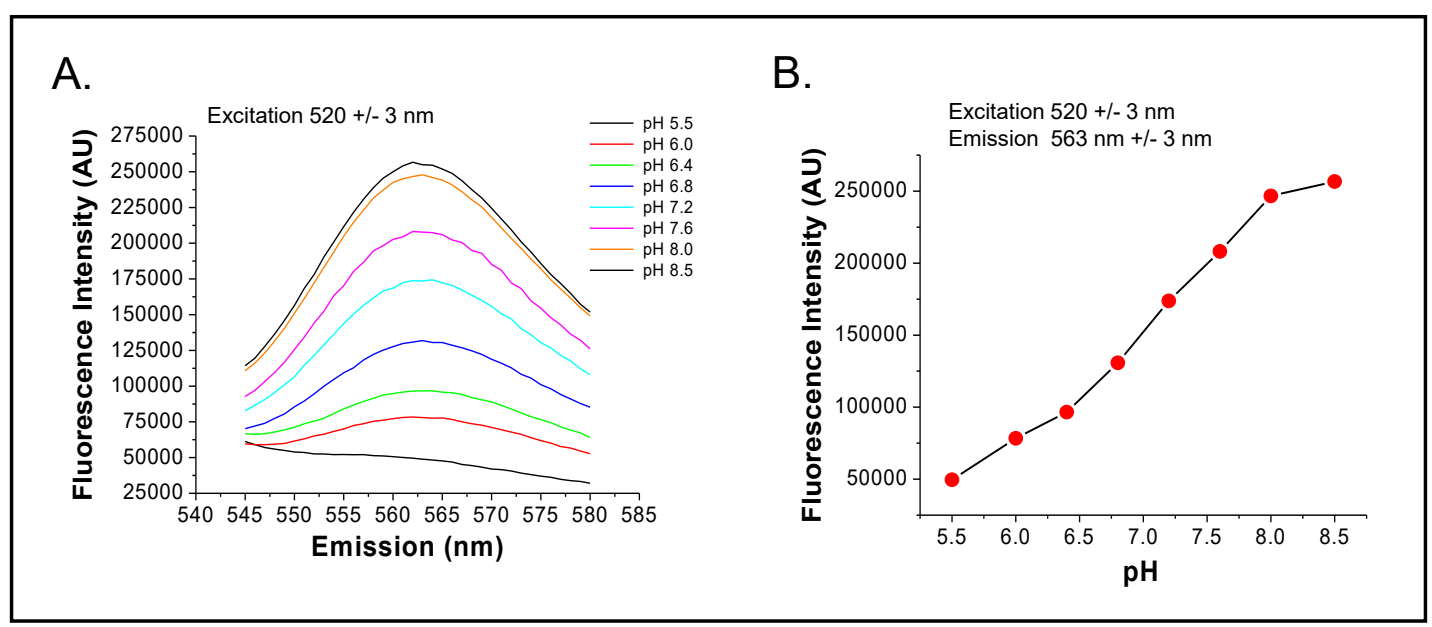

Fig. 4. Emission spectrum of mOrange 2 at different intracellular pHs. FRT/mOrange2/HA-NHE3 cells were grown on glass cover slides to confluent monolayers and were perfused with high potassium/nigericin solutions of indicated $\mathrm{pH}$ for at least $5 \mathrm{~min}$ to stabilize intracellular $\mathrm{pH}$. Excitation wave length was set at 520 $\pm 3 \mathrm{~nm}$ with emission at $565 \pm 3 \mathrm{~nm}$. Emission spectra of mOrange 2 at indicated pHs (5.5 to 8.5) are shown (A). Maximum intensity of mOrange 2 emission at different pHs was $563 \mathrm{~nm}$. Intensity of mOrange 2 emission at 563nm was plotted against corresponding intracellular pHs.

NHE3 activity quantitation using mOrange2 as $\mathrm{pH}$ sensor protein using a computerized fluorometer

Whether mOrange 2 could allow quantitation of NHE3 activity using dual excitation and single wave length emission in a fluorometer was determined in FRT/HA-NHE3/mOrange2 cells. Cells were grown on glass slides for 4-5 days, serum starved for $\sim 2$ hours and then bathed in $25 \mathrm{mM} \mathrm{NH}_{4} \mathrm{Cl}$ for $15 \mathrm{~min}$. Cells were then perfused with TMA to acidify the intracellular $\mathrm{pH}$, which after reaching a constant intensity, was then exposed to $\mathrm{Na}^{+}$solution which caused rapid alkalinization. Fig. $5 \mathrm{~A}$ shows the intensity of emission at $565 \pm 3 \mathrm{~nm}$ with $545 \pm 3 \mathrm{~nm}$ excitation under basal conditions in FRT cells expressing mOrange 2 without or with HA-NHE3 stably expressed, with all studies done in the presence of $10 \mu \mathrm{M}$ HOE-694. Results were similar with excitation $520 \pm 3 \mathrm{~nm}$. Cells expressing HA-NHE3 showed a rapid increase of mOrange 2 intensity representing intracellular alkalinization with $\mathrm{Na}^{+}$perfusion. Cells without HA-NHE3 had negligible change in mOrange 2 intensity with $\mathrm{Na}^{+}$perfusion.

We then tested the effect of $10 \mu \mathrm{M}$ forskolin exposed for $20 \mathrm{~min}$ before $\mathrm{Na}^{+}$addition on NHE3 activity in the same FRT/mOrange2/HA-NHE3 cells. Forskolin treatment inhibited NHE3 activity by 47\% compared to basal activity as shown in Fig. 5B.

\section{Stimulation of NHE3 by Dexamethasone}

To determine if NHE3 stimulation could be quantitated with mOrange2, we used short-term exposure to dexamethasone that is known to stimulate NHE3 activity, without altering the amount of NHE3 protein over this time [11,12]. Treatment of cells with $1 \mu \mathrm{M}$ dexamethasone for 5 hours stimulated NHE3 activity in FRT/HA-NHE3/mOrange2 cells in the presence of $10 \mu \mathrm{M}$ HOE-694. Dexamethasone treatment stimulated NHE3 activity by $41 \%$ and $48 \%$ stimulation in Clone \# 6 and \# 17 respectively (Fig. 6). These results indicate that NHE3 activitiy under basal, inhibited and stimulated conditions can be quantitated with mOrange2, producing quantitative results similar to those found using BCECF-AM $[11,12]$. 
A.

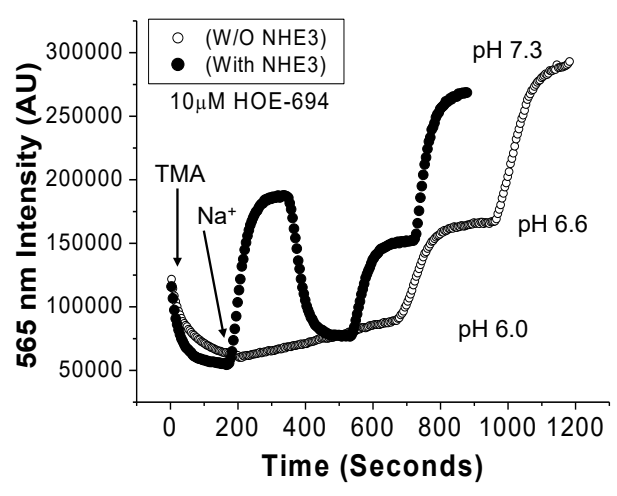

B.

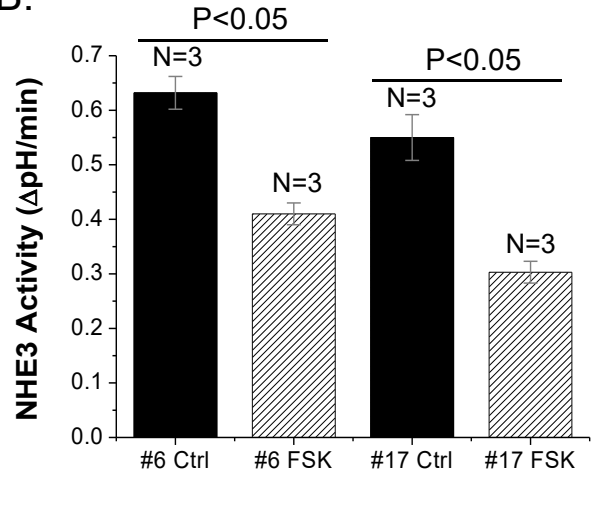

Fig. 5. Measurement of NHE3 activity in FRT/mOrange2/HA-NHE3 cells using mOrange2 as pH sensor protein in a computerized fluorometer. FRT/mOrange2/HA-NHE3 cells were grown on glass slides in confluent monolayers and NHE3 activity was measured in the presence of $10 \mu \mathrm{M}$ HOE-694. Traces of NHE3 activity in FRT/mOrange2 cells without (empty circle) and with HA-NHE3 expression (filled circle) are shown (A). NHE3 activity was measured from the initial rates of $\mathrm{Na}$-dependent intracellular alkalinization and calibrated with standards at three pHs. Calculated NHE3 activity under basal conditions and after $10 \mu \mathrm{M}$ forskolin treatment of clones \#6 and \#17 of FRT/mOrange2/HA-NHE3 cells is shown in bar graphs (B). Three experiments of each clone were averaged and mean \pm SEM and $p$ values are shown.

Fig. 6. Dexamethasone stimulates NHE3 activity in FRT/mOrange2/HA-NHE3 cells. NHE3 activity was measured in clones of FRT/mOrange2/HA-NHE3 cells treated with dexamethasone using mOrange2 as $\mathrm{pH}$ sensor probe in a computerized fluorometer. Cells treated for 5 hours with $1 \mu \mathrm{M}$ dexamethasone stimulated NHE3 activity in both clones \#6 and \#17 compared to basal activity. n, number of experiments. $\mathrm{p}$ values are comparison with basal NHE3 activity (paired t tests).

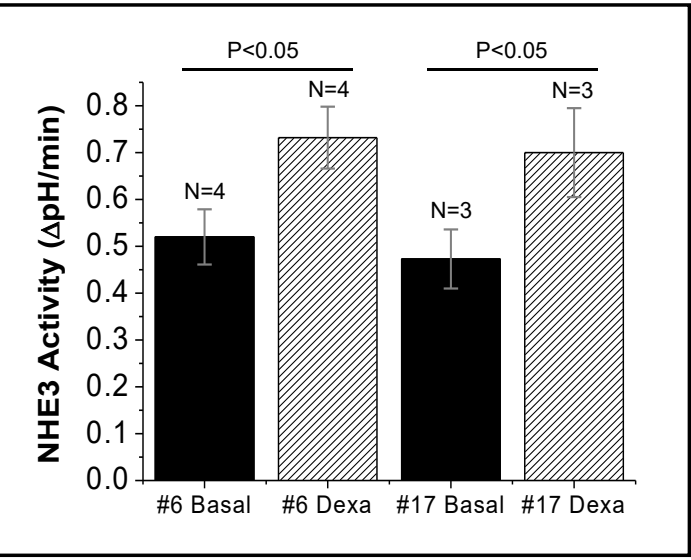

DRA activity quantitation using mOrange2 as $p H$ sensor protein using a computerized fluorometer

DRAactivity was quantitated in FRT/HA-NHE3/mOrange2 cells under basal and forskolin treated conditions. Since FRT cells do not endogenously express significant amounts of DRA, FRT/HA-NHE3/mOrange2 cells were transiently transfected with the pcDNA/FLAG-hDRA plasmid. Expression of FLAG-DRA and HA-NHE3 in FRT cells evaluated by immunoblot is shown in Fig. 7A. DRA activity was measured in the fluorometer using mOrange2. Traces of intracellular alkalinization driven by $\mathrm{HCO}_{3}{ }^{-}$entry after apical $\mathrm{Cl}^{-}$removal under basal and forskolin conditions are shown in Fig. 7B and calculated DRA activity is shown in Fig. 7C. DRA activity was stimulated $50 \%$ by forskolin treatment compared to basal activity. We then examined DRA activity in the FLAG-DRA transfected cells loaded with BCECF-AM dye. Basal and forskolin stimulated DRA activities are as shown in Fig. 7D and 7E. DRA activities measured using BCECF and mOrange2 were similar. These observations indicate that both NHE3 and DRA activities can be measured in live cells using mOrange2 as a pH sensor. 
A.

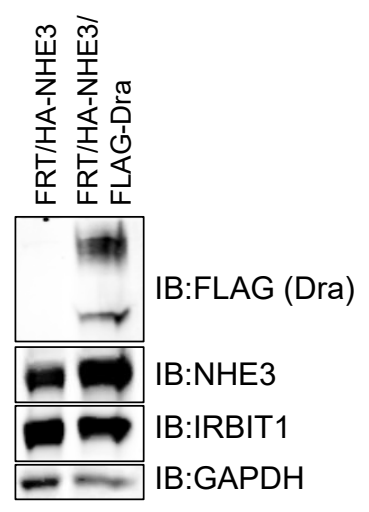

B.

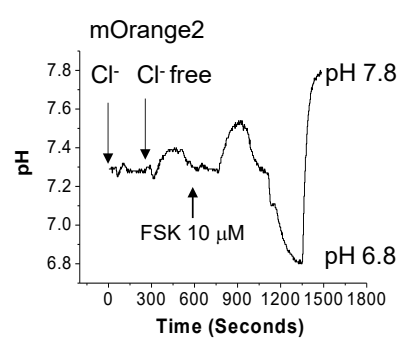

D.

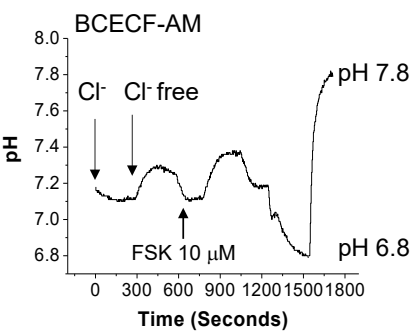

C.

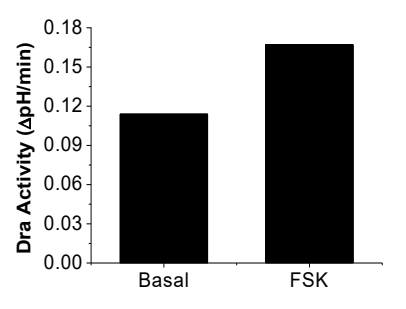

$\mathrm{E}$.

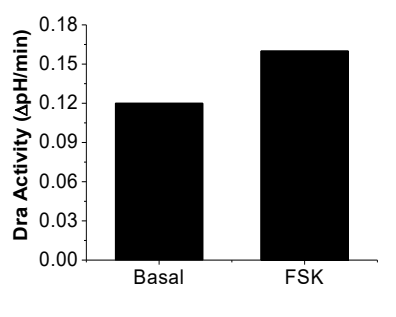

Fig. 7. DRA activity in FRT/mOrange2/HA-NHE3 cells transfected with FLAG-DRA. FRT/mOrange2/HANHE3 cells were grown on glass slides and transfected with pcDNA/FLAG-DRA plasmid. Expression of FLAG-DRA was verified by western blot analysis using anti-FLAG antibody (A). Traces of DRA activity under basal conditions (first peak) and after $10 \mu \mathrm{M}$ forskolin ( $2^{\text {nd }}$ peak) using mOrange 2 as the $\mathrm{pH}$ sensor in a computerized fluorometer are shown (B). DRA activity under these conditions is shown in the bar graph (C). For comparison, we measured DRA activity in FLAG-DRA transfected FRT/mOrange2/HA-NHE3 cells using BCECF-AM as pH sensor dye. Traces of basal and forskolin treated DRA activity are shown in (D) and calculated DRA activity under basal and forskolin stimulated condition is shown in the bar graph (E).

\section{Discussion}

We have established a convenient assay to measure intracellular $\mathrm{pH}$ change due to NHE3 or DRA activity in epithelial cells using a genetically modified protein, mOrange 2 as a $\mathrm{pH}$ sensor probe which can be uniformly expressed in the cells studied. Recent development and description of its properties [13-15] encouraged us to investigate whether it could be used to measure NHE3 and DRA activity in live cells. mOrange2 is a fluorescent protein, derived from mOrange after 4 single mutations by which photo-stability is increased significantly [13]. The pKa value of mOrange 2 is 6.5 , which is within the $\mathrm{pH}$ range that both NHE3 and DRA are active. There are multiple positive properties of mOrang2 to serve as a pH indicator in live cells; these include uniform labeling of cells, resistance of bleaching, and, since it is a protein that is expressed intracellularly, dye leaking as occurs with AM dyes does not occur. In addition, it can be targeted to specific subcellular locations by including association sequences.

In FRT cells, using mOrange 2 as $\mathrm{pH}$ sensor, $\mathrm{Na}^{+} / \mathrm{H}^{+}$exchanger induced intracellular alkalinization was seen microscopically by changes in mOrange 2 fluorescence; and changes in the fluorescence intensity occurred with both inhibition and stimulation by forskolin and dexamethasone, respectively. Observations made in the current studies support that mOrange 2 can be used to measure pHi in a 96 well format, which could be used for drug screening or other large-scale studies. Recommended settings, excitation $520 \mathrm{~nm}$, emission $563 \mathrm{~nm}$.

NHE3 activity measured in FRT/HA-NHE3 cells using the fluorometer and either BCECF or mOrange 2 revealed similar rates of $\Delta \mathrm{pH} / \mathrm{min}$, a surrogate for rates of $\mathrm{Na}^{+} / \mathrm{H}^{+}$exchange activity. Using mOrange2, NHE3 activity was inhibited 30 to $50 \%$ with forskolin treatment 


\section{Cellular Physiology Cell Physiol Biochem 2022;56:39-49

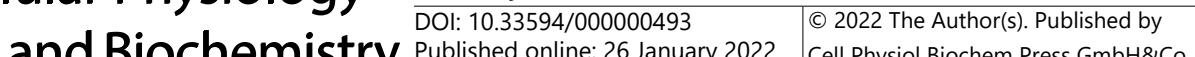 \\ Published online: 26 January 2022 Cell Physiol Biochem Press GmbH\&Co. KG \\ Sarker et al.: mOrange2 to Measure NHE3 and DRA Activity}

compared to untreated cells and stimulated $40-50 \%$ by dexamethasone treatment. These were results similar to those reported previously in studies using BCECF [9-11]. Similarly, the measurements of DRA driven $\mathrm{Cl}^{-} / \mathrm{HCO}_{3}^{-}$exchange rates measured in the same cells using BCECF and mOrange 2 produced very similar basal activity measurements as well as extent of stimulation by forskolin treatment. These results strongly support the usefulness of mOrange 2 for study of regulation of $\mathrm{pHi}$ in living cells and for measuring transport rates over the $\mathrm{pH}$ range delineated by its $\mathrm{pKa}$.

There are multiple reports of mOrange 2 use to measure $\mathrm{pHi}$ in the live cells. Li et al. [14] developed an assay with a $\mathrm{pH}$-sensitive fluorescent IRAP-mOrange2 probe to measure insulin-stimulated GLUT4 translocation from GLUT4 storage vesicles (GSVs) to the plasma membrane. Egashira et al. [15] measured re-acidification kinetics during synaptic vesicle (SV) recycling in cultured hippocampal neurons using a mOrange2-based probe. This report is the initial documentation of its usefulness in quantitating NHE3 and DRA activity and its use in epithelial cells.

In summary, we have established mOrange 2 as an efficient $\mathrm{pH}$-sensitive fluorescent probe to measure NHE3 and DRA activity in epithelial cells, which would be useful in the study of NHE3 and DRA regulation in individual experiments and high throughput studies.

\section{Acknowledgements}

We thank Alan Verkman for providing the FRT cells and Dr. Hans-Jochen Lang for providing the HOE-694.

\section{Author Contributions}

R. Sarker, M. Tse, R. Lin, and V. Singh performed the experiments, analyzed the data and planned additional studies. R. Lin development methods to generate the monolayers and prepared the monolayers used. G. McNamara helped standardize the fluorometric studies and establish best way to quantitate intracellular $\mathrm{pH}$. M. Donowitz devised concept of studies, planned experiments, interpreted results, prepared the manuscript and provided funding for the study. All authors helped in manuscript preparation.

\section{Funding}

This study was supported in part by NIH grants R01-DK26523, R01-DK61765, P01DK64388, NIH SIG 1S100D025244, P30-DK89502, and P01-AI125181.

\section{Disclosure Statement}

The authors declare that no conflict of interests exists.

\section{References}

1 Spencer AG, Labonte ED, Rosenbaum DP, Plato CF, Carreras CW, Leadbetter MR, Kozuka K, Kohler J, KooMcCoy S, He L, Bell N, Tabora J, Joly KM, Navre M, Jacobs JW, Charmot D: Intestinal inhibition of the Na+/ $\mathrm{H}+$ exchanger 3 prevents cardiorenal damage in rats and inhibits $\mathrm{Na}+$ uptake in humans. Sci Transl Med 2014;6:227ra36.

2 Haggie PM, Cil O, Lee S, Tan JA, Rivera AA, Phuan PW, Verkman AS: SLC26A3 inhibitor identified in small molecule screen blocks colonic fluid absorption and reduces constipation. JCI Insight 2018;3:e121370.

3 Zachos NC. Vaughn H, Sarker R, Lin R, Tse CM, Green J, Donowitz M: 266 NHE3 is a Drug Target for Treating Diarrhea: A Novel Peptide Stimulates NHE3 Activity, Prevents cAMP, cGMP, and Ca2+ Inhibition of NHE3 and Prevents Cholera Toxin and E. coli Heat Stable Enterotoxin Fluid Secretion. Gastroenterology 2021;160:S63-S64. 


\section{Cellular Physiology Cell Physiol Biochem 2022:56:39-49 \begin{tabular}{ll|l} 
DOI: 10.33594/000000493 & ब 2022 The Author(s). Published by \\
and Biochemistry & Published online: 26 January 2022 & Cell Physiol Biochem Press GmbH\&Co. KG \\
\cline { 2 - 3 }
\end{tabular} \\ Sarker et al.: mOrange2 to Measure NHE3 and DRA Activity}

4 Ma T, Thiagarajah JR, Yang H, Sonawane ND, Folli C, Galietta LJV, Verkman AS: Thiazolidinone CFTR inhibitor identified by high-throughput screening blocks cholera toxin-induced intestinal fluid secretion. J Clin Invest 2002;110:1651-1658.

5 Cil O, Phuan P-W, Lee S, Tan J, Haggie PM, Levin MH, Sun L, Thiagarajah JR, Ma T, Verkman AS: CFTR activator increases intestinal fluid secretion and normalizes stool output in a mouse model of constipation. Cell Mol Gastroenterol Hepatol 2016;2:317-327.

6 Roos A, Boron WF: Intracellular pH. Physiol Rev 1981;61:296-434.

7 Janecki AJ, Montrose M H, Zimniak P, Zweibaum A, Tse C M, Khurana S, Donowitz M: Subcellular redistribution is involved in acute regulation of the brush border $\mathrm{Na} / \mathrm{H}$ exchanger isoform 3 in human colon adenocarcinoma cell line Caco-2. Protein kinase C-mediated inhibition of the exchanger. J Biol Chem 1998;273:8790-8798.

8 Sarker R, Grønborg M, Cha M, Mohan S, Chen Y, Pandey A, Litchfield D, Doniwtz M, Li X: Casein kinase 2 binds to the $\mathrm{C}$ terminus of $\mathrm{Na}+\mathrm{H}+$ exchanger 3 (NHE3) and stimulates NHE3 basal activity by phosphorylating a separate site in NHE3. Mol Biol Cell 2008;19:3859-3870.

9 Sarker R, Valkhoff VE, Zachos NC, Lin R, Cha B, Chen TE, Guggino S, Zizak M, de Jonge H, Hogema B, Donowitz M: NHERF1 and NHERF2 are necessary for multiple but usually separate aspects of basal and acute regulation of NHE3 activity. Am J Physiol Cell Physiol 2011;300:C771-C782.

10 Tse CM, Yin J. Singh V, Sarker R, Lin R, Verkman AS, Turner JR, Donowitz M: cAMP Stimulates SLC26A3 Activity in Human Colon by a CFTR-Dependent Mechanism That Does Not Require CFTR Activity. Cell Mol Gastroenterol Hepatol 2019;7:641-653.

11 Bobulescu A, Dwarakanath V, Zou L, Zhang J, Baum M, Moe OW: Glucocorticoids acutely increase cell surface $\mathrm{Na}+\mathrm{H}+$ exchanger-3 (NHE3) by activation of NHE3 exocytosis. Am J Physiol Renal Physiol 2005;289:F685-F691.

12 Wang D, Zhang H, Lang F, Yun CC: Acute activation of NHE3 by dexamethasone correlates with activation of SGK1 and requires a functional glucocorticoid receptor. Am J Physiol Cell Physiol 2007;292:C396-C404.

13 Shaner NC, Lin MZ, McKeown MR, Steinbach PA, Hazelwood KL, Davidson MW, Tsien RY: Improving the photostability of bright monomeric orange and red fluorescent proteins. Nat Methods 2008;5:545-551.

14 Li Y, Zheng L, Wang D, Zhang X, Li J, Ali S, Zong H, Xu X: Staurosporine as an agonist for induction of GLUT4 translocation, identified by a $\mathrm{pH}$-sensitive fluorescent IRAP-mOrange2 probe. Biochem Biophys Res Commun 2016;25:534-538.

15 Egashira Y, Takase M Takamori S: Monitoring of Vacuolar-Type H+ ATPase-Mediated Proton Influx into Synaptic Vesicles. J Neurosci 2015;35:3701-3710. 